\title{
Intersectoral Collaborations for the Prevention and Control of Vector Borne Diseases: A Scoping Review
}

\author{
Ma. Sophia Graciela L. Reyes, ${ }^{1}$ Chelseah Denise H. Torres, ${ }^{1}$ Amiel Nazer C. Bermudez, ${ }^{2}$ Kim L. Cochon, ${ }^{2}$ \\ Evalyn A. Roxas, ${ }^{3,4}$ Sophia Anne S.P. Liao, ${ }^{1}$ Dorothy Jean N. Ortega, ${ }^{1}$ Abegail Visia Marie C. Silang, ${ }^{1}$ \\ Deinzel R. Uezono, ${ }^{1}$ Maria Sonia S. Salamat ${ }^{4}$ and Carl Abelardo T. Antonio ${ }^{5,6}$ \\ ${ }^{1}$ College of Public Health, University of the Philippines Manila, Manila, Philippines \\ ${ }^{2}$ Department of Epidemiology and Biostatistics, College of Public Health, University of the Philippines Manila, Manila, Philippines \\ ${ }^{3}$ Department of Medical Microbiology, College of Public Health, University of the Philippines Manila, Manila, Philippines \\ ${ }^{4}$ Department of Medicine, College of Medicine and Philippine General Hospital, University of the Philippines Manila, Manila, Philippines \\ ${ }^{5}$ Department of Health Policy and Administration, College of Public Health, University of the Philippines Manila, Manila, Philippines \\ ${ }^{6}$ Department of Applied Social Sciences, The Hong Kong Polytechnic University, Kowloon, Hong Kong
}

\begin{abstract}
Objectives. This scoping review aimed to support a landscape analysis to identify lessons learned about intersectoral collaborations (ISCs) by describing their existing models in the context of dengue, malaria and yellow fever.

Methods. A scoping review following the methodology of Joanna Briggs Institute was performed using the following inclusion criteria: studies involving humans; studies discussing intersectoral collaborations, malaria/dengue/yellow fever, and prevention or control at any level; and studies in countries endemic for the aforementioned diseases. Studies were screened using Covidence, while data were extracted using NVivo.
\end{abstract}

Results. Of the 7,535 records retrieved, 69 were included in the qualitative analysis. Most ISCs were initiated by multilateral organizations and ministries of health, and none by communities. Strategies included advocacy, health education, research, public health measures, resource mobilization, service delivery and training; mostly employed on a community level. Monitoring and evaluation were mostly formative, ongoing, and participatory. Gaps included administrative and policy barriers, resource shortages, and inadequate research and training.

Conclusions. Multiple models of ISC exist in the literature. There is a need to develop a comprehensive framework for an effective and sustainable multisectoral approach for the prevention and control of VBDs ensuring adequate resources, active stakeholders, and strategies that span the entire socio-ecological spectrum.

Key Words: dengue, disease vectors, intersectoral collaboration, malaria, review [Publication Type], vector borne diseases, yellow fever

\section{INTRODUCTION}

Vector-borne diseases both impede human development and result from a lack thereof, having the highest burden in the least developed populations in the world. ${ }^{1}$ In recent years, there has been an increase in the number of cases and fatalities from arboviral infections other than malaria such as dengue and yellow fever, despite strong prevention and control efforts. Malaria case incidence has fallen by around $18 \%$ since 2010, however the rate of decline has stalled and in some cases reversed between 2014 and 2016. ${ }^{2}$

Corresponding author: Carl Abelardo T. Antonio, MD, MPH Department of Health Policy and Administration College of Public Health

University of the Philippines Manila

Lara Hall, 625 Pedro Gil Street, Ermita, Manila 1000, Philippines

Telephone +6323428932

E-mail: ctantonio@up.edu.ph
According to the 2013 Global Burden of Disease Study, the incidence of dengue more than doubled every decade from 1990 to $2013 .^{3}$ However, the actual numbers of cases are underreported and misclassified, with a large discrepancy between academic estimates and reported burden due to a lack of capacity for surveillance. 
The Multisectoral Action Framework for Malaria (MAFM) initiated by the United Nations Development Program (UNDP) called for action in multiple sectors to complement existing malaria control strategies. Its goal was to present implementable actions for countries to transform malaria processes from being solely a health sector responsibility to a shared responsibility via a multi-pronged approach. After its launch in 2016, there has been a standing initiative to expand the MAFM to other vector-borne diseases, in the context of the Sustainable Development Goals. ${ }^{4}$ The WHO currently recommends Integrated Vector Management (IVM) for the prevention and control of dengue, however data on its impact on the disease was deemed insufficient. One of the key elements for the successful implementation of IVM is collaboration through the optimal use of resources, monitoring and decision-making; however, in the context of dengue, the extent of collaboration and challenges in implementation globally is vague. ${ }^{5}$

This scoping review aimed to support a landscape analysis to better identify the knowledge gaps and lessons learned about inter-sectoral collaborations for the prevention and control of vector-borne diseases and how stakeholders are working together to achieve the implementation of a global strategy by describing existing models and frameworks related to inter-sectoral collaborations for the prevention and control of selected vector-borne diseases - specifically dengue, malaria, and yellow fever, alongside strong efforts to prevent and control malaria.

\section{METHODS}

\section{Scoping Review of Literature}

A scoping review of literature, which is "aimed at mapping key concepts, types of evidence, and gaps in research related to a defined area or field by systematically searching, selecting, and synthesizing existing knowledge", was conducted to address the study objectives, adopting the methodology of Arksey \& O'Malley (2005) and Levac, Colquhoun, \& O'Brien (2010) as collated by The Joanna Briggs Institute..$^{6-9}$

This scoping review addressed the question, "What models of inter-sectoral collaborations have been implemented in countries where vector-borne diseases are a priority issue, and what are documented effects on the prevention of vector-borne diseases?".

Records that satisfied all of the following criteria were considered for inclusion in the review: (1) discusses the population, concept AND context parameters contained in the research question, (2) any type of article, e.g., case studies, primary researches, reviews, editorials, etc., (3) accessible full-text article, (4) available in the English language, and (5) published between 01 January 1985 and 31 December 2016. These criteria, which were determined a priori, were selected to increase the sensitivity or comprehensiveness of the search, consistent with the intent of a scoping review.
A preliminary search of PubMed was done using search terms categorized into population, concept, and context. Population included studies with humans; concept included studies that tackled (a) intersectoral collaborations, (b) malaria/dengue/yellow fever, and (c) prevention/ control at any level; and context included studies that discussed countries endemic for malaria, yellow fever, and/ or dengue. A secondary search of all included databases (i.e. PubMed, Scopus, ProQuest Central and the Public Library of Science/PLoS) was then conducted using the expanded list of search terms. All records obtained from the different databases were deduplicated manually, and by using EndNote $^{\mathrm{TM}}$ X8 (Thomson Reuters, 2016) ${ }^{\mathrm{a}}$ and Covidence

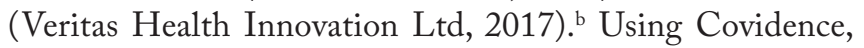
abstracts of the records were each screened independently by two reviewers, and conflicts were resolved by an arbitrator. Included records were moved to full-text screening, where they were further scrutinized. If a study met the inclusion criteria, the full-text was imported to NVivo 11 Pro (Version 11.3; QSR International Pty Ltd, 2016) ${ }^{c}$ for qualitative data analysis. Data from the final list of included records were extracted using NVivo. Reference lists of records included for qualitative data analysis were examined, and records assessed to be relevant for the study were subjected to both abstract and full-text screening. No hand searching was done, and articles that required purchase for full-text accessibility were not included due to feasibility considerations.

Data on study characteristics (e.g. author/s, publication year, country of origin, type of publication), aims and methods of the publication, outcomes measured, stakeholders and proponents of the intersectoral collaboration, source of funding and resources used by the collaboration, goals and outcomes, strategies employed, mechanisms for monitoring and evaluation, and the gaps in policy, research, and training were identified from the full-text of the article, and coded into nodes pre-specified according to review objectives using NVivo (Appendix). Data abstracted from the selected records were determined from the standard list as prescribed by The Joanna Briggs Institute, modified to suit the objectives of the review. As major themes and constructs emerged, in-vivo nodes were either expanded or merged with existing nodes. Data on the country of

a EndNote is a software that acts as a reference manager. Its features include deduplication of references, integration with Microsoft Word, and reference organizing, among others. For further information, readers may visit https://endnote.com/productdetails/.

b Covidence is a screening and data extraction tool which allows a team to undertake most of the labor-intensive steps in a review process. For further information, readers may visit https:// community.cochrane.org/help/tools-and-software/covidence/ about-covidence.

c NVivo is a qualitative data analysis software that aids in the organization, analysis, synthesis, and visualization of qualitative and mixed-methods data. For further information, readers may visit https://www.qsinternational.com/nvivo/what-is-nvivo. 


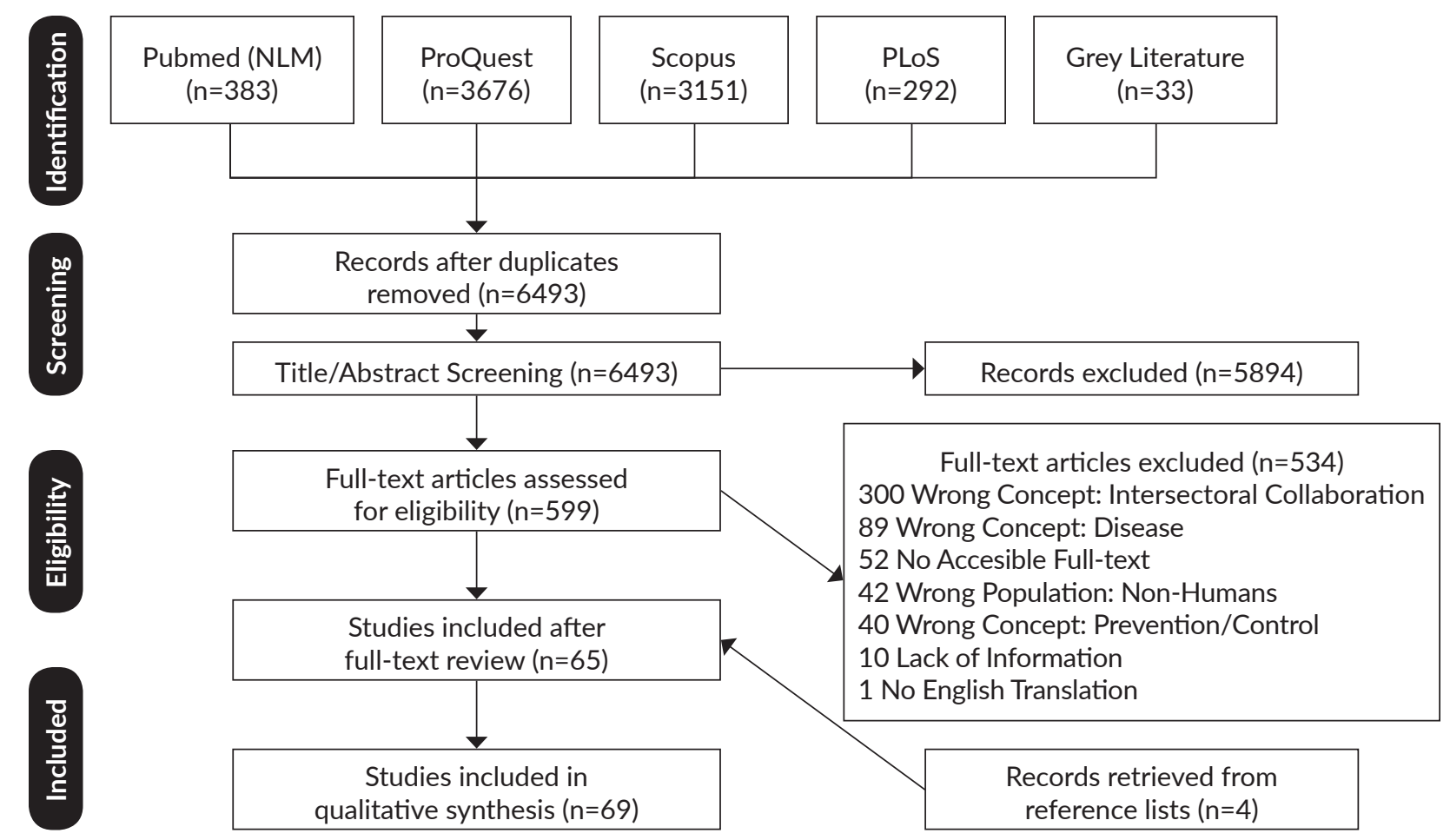

Figure 1. PRISMA Flow Diagram.

origin of all studies was synthesized and visualized using the mapping functionality of Tableau (Tableau Software) ${ }^{\mathrm{d}}$. After the coding of data from all included studies, data was synthesized by cross-tabulating nodes.

\section{RESULTS}

The scoping review yielded 7,535 records, of which 69 were included in qualitative data analysis following title and abstract screening, full-text assessment, and review of reference lists (Figure 1). ${ }^{11-79}$

Out of the 69 records included in the review, $11.6 \%$ were published in 2005, and 39.1\% were original journal articles. Other articles included conference proceedings, institutional reports, journal articles (commentaries), journal articles (reviews), periodicals, theses/dissertations, and websites. The countries with the greatest number of published records were Tanzania (15), Kenya (12), Ghana (10), Uganda (10), and Zambia (10) (Figure 2). There were 59 records that discussed malaria and 13 records that discussed dengue fever. No literature for yellow fever was found.

For this review, the different intersectoral collaborations (ISCs) were named based on the type of control program (i.e. either dengue or malaria, and the place involved). These

d Tableau is a data visualization software which has an interactive data mapping feature through the use of built-in postal codes, latitudes, and longitudes. For more information, readers may visit https://www.tableau.com/products/desktop. include the following: the Malaria Control Programme (MCP); Dengue Control Programme (DCP); Roll Back Malaria (RBM); Multilateral Initiative for Malaria (MIM); Asian Centre of International Parasite Control (ACIPAC); Global Fund for AIDS, Tuberculosis, and Malaria (GFATM); Primary Health Care (PHC) for Nepal; and Integrated Vector Management (IVM).

\section{Structure and Composition of Intersectoral Collaborations}

Majority of the intersectoral collaborations were initiated by multilateral organizations and ministries of health, and none by community-based organizations. Table 1 shows the overall distribution of stakeholders, with gray cells indicating the proponents of the collaborations.

Thirty organizations assisted in the funding of the various collaborations. Seventeen of these funders belonged to the public sector, mainly other development aid agencies. There were five institutions of mixed-type ownership (GFATM, RBM, WHO, International Development Research Centre (IDRC), and the Pan American Health Organization (PAHO)). Funding of most ISCs identified were mostly sourced from government of the country involved. ${ }^{10,19,28,32,33,35,39,45,55,56,69,75}$ Meanwhile, other collaborations were funded directly by the GFATM, the US Agency for International Development (USAID), as well as the IDRC. $11,18,19,24,27,34,48,53,56,62,65,71,75,77$

The most frequently occurring resources used were human resources - researchers and health 
Table 1. Summary of stakeholders per Intersectoral Collaboration

\begin{tabular}{|c|c|c|c|c|c|c|c|}
\hline Official Name of ISC & $\begin{array}{c}\text { Academe and } \\
\text { Research Institutes }\end{array}$ & $\begin{array}{l}\text { Civil Society } \\
\text { Organization }\end{array}$ & Community & $\begin{array}{l}\text { Government Agency } \\
\text { - Ministry of Health }\end{array}$ & $\begin{array}{c}\text { Government } \\
\text { Agency - Other }\end{array}$ & Industry & $\begin{array}{c}\text { Multilateral } \\
\text { Organization }\end{array}$ \\
\hline ACIPAC & 4 & 5 & 1 & 3 & 4 & 1 & 7 \\
\hline $\mathrm{DCP}^{1}$ & 1 & 1 & 0 & 0 & 0 & 0 & 1 \\
\hline $\begin{array}{l}\text { DCP Latin America } \\
\text { and Caribbean }{ }^{2}\end{array}$ & 4 & 1 & 5 & 7 & 6 & 1 & 8 \\
\hline DCP Asia ${ }^{3}$ & 2 & 0 & 5 & 2 & 2 & 0 & 0 \\
\hline GFATM Uganda & 0 & 0 & 0 & 1 & 0 & 0 & 0 \\
\hline IVM & 0 & 0 & 0 & 1 & 0 & 0 & 1 \\
\hline $\mathrm{RBM} \& \mathrm{MIM}^{4}$ & 13 & 27 & 3 & 3 & 12 & 12 & 27 \\
\hline MCP & 6 & 5 & 1 & 5 & 6 & 2 & 18 \\
\hline MCP Africa ${ }^{5}$ & 47 & 17 & 22 & 29 & 30 & 8 & 27 \\
\hline MCP Latin America ${ }^{6}$ & 5 & 7 & 0 & 5 & 8 & 2 & 8 \\
\hline MCP Asia ${ }^{7}$ & 4 & 2 & 4 & 5 & 8 & 3 & 1 \\
\hline MCP Papua New Guinea & 0 & 1 & 0 & 0 & 1 & 0 & 1 \\
\hline PHC Nepal & 0 & 0 & 0 & 1 & 0 & 0 & 0 \\
\hline
\end{tabular}

1 DCP and DCP (Ecohealth)

2 DCP Argentina, DCP Brazil, DCP Cuba (Havana), DCP Cuba (Santiago de Cuba), DCP Americas, DCP Americas (Service Delivery), DCP Caribbean 3 DCP China, DCP Vietnam, DCP Sri Lanka

4 Multilateral Initiative on Malaria, Roll Back Malaria Afghanistan, RBM \& MIM

5 MCP Africa, MCP East Africa (Ecohealth), MCP East and Central Africa (Ecohealth), MCP Ghana, MCP Kenya, MCP Kenya and Tanzania, MCP Tanzania, MCP Tanzania (CONTACT), MCP Tanzania (Urban), MCP Tanzania (Voucher), MCP Zambia 6 MCP Argentina, MCP Brazil, MCP Colombia, MCP Latin America, MCP Mesoamerica and Hispaniola

7 MCP China, MCP India (Kheda Project), MCP Laos, MCP Malaysia, MCP Thailand
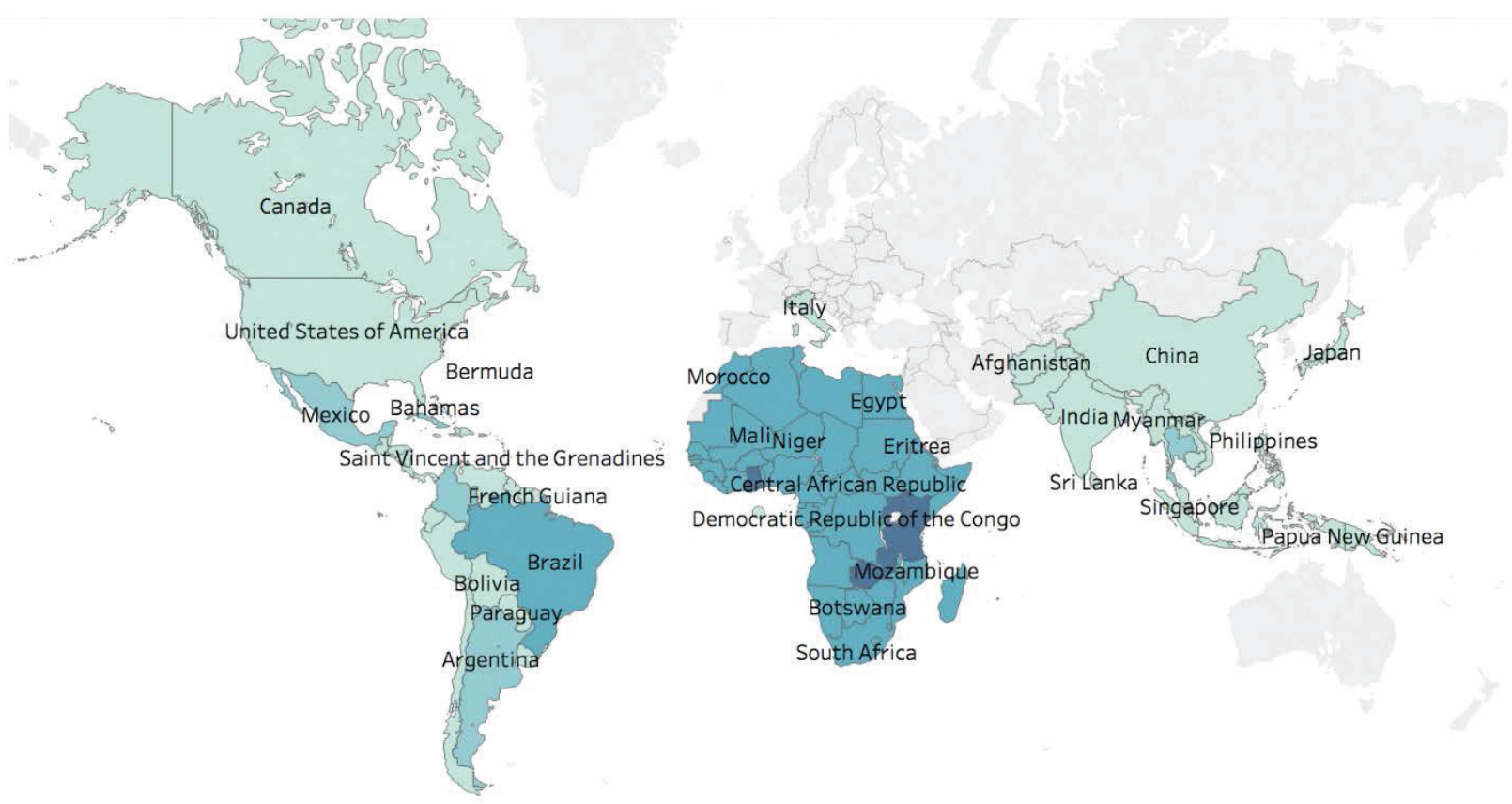

Color gradient reflects the number of multisectoral collaborations identified in each country

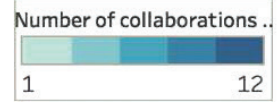

Figure 2. Distribution of intersectoral collaborations for malaria and/or dengue prevention and control, by country/territory. 
workers such as physicians, malariologists, and public health officers; environmental consultants such as vector control technicians and entomologists; and community leaders, members, teachers, and volunteers (Table 2). ${ }^{10-13,19,20,23,25,27,28,32-34,36,38,40,42,43,48,50,55,58,59,61,63,65,67,71,76-78}$

\section{Strategies for ISCs}

Strategies employed were classified into the CDC's social ecological model of health, further being classified into type of strategy, as summarized in Table 3. Most strategies were employed on the community level, followed by the policy level. Only three categories - health education, public health measures, and training - had interpersonallevel strategies (Table 3).

\section{Monitoring and Evaluation}

Monitoring and evaluation mechanisms were classified based on the nature of the goal, their duration, and the extent to which the evaluators were involved (i.e. whether they were formative or summative, one-shot or ongoing, and participatory or objectively observational, respectively). Formative evaluations are those that normally occur during a project's implementation, with the aim to improve on the current program design, while summative evaluations are those that simply want to summarize the impact or outcome of a project. One-shot evaluations are those conducted at the end of a program without any information having been collected beforehand, while ongoing evaluations are those that continuously occur throughout the duration of the project. Participatory evaluation is conducted by actively engaging stakeholders of the program, including community members and state authorities; while objective observation is normally conducted by researchers or an external party with the sole task of evaluating the project without involving stakeholders. Nineteen ISCs were found to have employed formative methods of evaluation, while eight employed summative methods; 19 ISCs had ongoing methods of monitoring and evaluation while seven had one-shot methods; and 13 ISCs used participatory mechanisms, while another 13 used objective observations. ${ }^{13,16,17,20,21,27,28,30,32,34-36,38,}$ 40-43,45,47,50,51,53,56,58,60,61,63,65-68,71,73,78 Mechanisms for monitoring and evaluation were not identified in 22 records.

\section{Goals and Outcomes}

Initiatives for the prevention and control of vectorborne diseases all had the same goal - to reduce morbidity and mortality rates of vector-borne diseases. Among the ISCs that used advocacy or health promotion strategies, it was only the Malaria Control Programme in Africa that indicated a specific goal, which was to develop national research policies for the resolution of national problems. ${ }^{33}$ A summary of specific ISC goals and their resulting outputs and outcomes are summarized in Table 4.

As a result of these ISCs, collaborative committees were formed in communities where there were previously none. ${ }^{25,33,40}$ Existing vector control programs and networks expanded to areas surrounding the pilot communities, and international summits and community meetings were conducted for the discussion of these diseases and their control. $30,58,65,69,73$ Teamwork and coordination skills of the various stakeholders were also enhanced as a result of their frequent interactions, and the empowerment of the communities together with intersectoral coordination allowed for the sustainability and even expansion of the projects after withdrawal of external support. ${ }^{30,32,55,58,65}$

The impact of all the strategies employed by the ISCs was seen in a decrease in the morbidity and mortality rates of dengue and malaria, and in behavioral changes such as increased stakeholder participation and community ownership. ${ }^{16,25,27,32,42,44,55,61}$ Control programs were strengthened through the adoption of technology and an increase in resources. Overall, malaria and dengue were recognized as problems in the community that are controllable and preventable through combined local and international efforts.

Table 2. Resources used by ISCs for the prevention and control of vector-borne diseases

\begin{tabular}{|c|c|c|c|c|c|c|c|}
\hline \multicolumn{3}{|c|}{ Material } & \multirow{2}{*}{ Human } & \multirow{2}{*}{ Financial } & \multicolumn{3}{|c|}{ Policy } \\
\hline Infrastructure & Equipment & Supplies & & & Legislation & Support & Mobilization \\
\hline $\begin{array}{l}\text { - Laboratory } \\
\text { facilities } \\
\text { - Anti-malaria } \\
\text { centers } \\
\text { - Research } \\
\text { and training } \\
\text { centers } \\
\text { - On-site clinics } \\
\text { - Project } \\
\text { headquarters } \\
\text { and offices }\end{array}$ & $\begin{array}{l}\text { - Laboratory } \\
\text { equipment } \\
\text { - Technical } \\
\text { equipment } \\
\text { - Storage } \\
\text { equipment } \\
\text { - Vehicles }\end{array}$ & $\begin{array}{l}\text { - Insecticide- } \\
\text { treated } \\
\text { bed nets } \\
\text { - Medicines } \\
\text { - Promotional } \\
\text { materials } \\
\text { - Educational } \\
\text { materials }\end{array}$ & $\begin{array}{l}\text { - Health workers } \\
\text { - Entomology and } \\
\text { environmental } \\
\text { experts } \\
\text { - World leaders, } \\
\text { government } \\
\text { officials } \\
\text { - Teachers, } \\
\text { students, } \\
\text { parents } \\
\text { - Researchers } \\
\text { - Technicians and } \\
\text { operators } \\
\text { - Community } \\
\text { members } \\
\end{array}$ & $\begin{array}{l}\text { Monetary } \\
\text { assistance from } \\
\text { the ff: } \\
\text { - Governments } \\
\text { - Private } \\
\text { institutions } \\
\text { - Multilateral } \\
\text { organizations } \\
\text { - Philanthropic } \\
\text { foundations }\end{array}$ & $\begin{array}{l}\text { - Creation of } \\
\text { a malaria } \\
\text { committee } \\
\text { - Formulation } \\
\text { of strategic } \\
\text { plans for } \\
\text { control } \\
\text { - Development } \\
\text { of school and } \\
\text { occupational } \\
\text { health policies } \\
\text { - International } \\
\text { declarations } \\
\text { - Foreign } \\
\text { relations }\end{array}$ & $\begin{array}{l}\text { - Endorsement } \\
\text { and adoption } \\
\text { of the ISC } \\
\text { projects } \\
\text { by the } \\
\text { government } \\
\text { - Strong } \\
\text { political } \\
\text { commitment }\end{array}$ & $\begin{array}{l}\text { - Provision of } \\
\text { human and } \\
\text { financial } \\
\text { resources } \\
\text { by national } \\
\text { and local } \\
\text { governments } \\
\text { - Government } \\
\text { promotion and } \\
\text { encouragement } \\
\text { of community } \\
\text { participation }\end{array}$ \\
\hline
\end{tabular}


Table 3. Strategies of the various ISCs distributed across the social ecological model of health

\begin{tabular}{|c|c|c|c|c|}
\hline & Interpersonal & Organization & Community & Policy \\
\hline Advocacy & & $\begin{array}{l}\text { - Negotiation with } \\
\text { pharmaceutical industry } \\
\text { for affordable prices of } \\
\text { new drug combinations }\end{array}$ & $\begin{array}{l}\text { - Holistic approaches to management (IVM) } \\
\text { - Collaboration between local government and } \\
\text { technical experts } \\
\text { - Social mobilization, media campaigns and community } \\
\text { health promotion } \\
\text { - School-based activities using the participatory } \\
\text { learning action (PLA) approach } \\
\text { - Social marketing of insecticide treated materials }\end{array}$ & $\begin{array}{l}\text { - Program creation for malaria } \\
\text { by multinational groups } \\
\text { Implementation of } \\
\text { comprehensive legislations } \\
\text { - Regulation of activities } \\
\text { related to VBD transmission } \\
\text { - Calls to action for health } \\
\text { systems strengthening } \\
\text { - Increase in investment } \\
\text { against malaria } \\
\text { - Establishment of networks } \\
\text { at regional, national and } \\
\text { international levels }\end{array}$ \\
\hline $\begin{array}{l}\text { Health } \\
\text { Education }\end{array}$ & $\begin{array}{l}\text { - Usage of the } \\
\text { child-to-child } \\
\text { approach } \\
\text { - Face-to-face } \\
\text { encounters } \\
\text { for health } \\
\text { promotion }\end{array}$ & $\begin{array}{l}\text { - Development of curricula } \\
\text { and model schools for } \\
\text { malaria prevention } \\
\text { - Decentralization of school } \\
\text { supervision }\end{array}$ & $\begin{array}{l}\text { - Campaigns spearheaded by students and teachers } \\
\text { to raise awareness about malaria using creative } \\
\text { methods (e.g. plays, performances, and visual aids) } \\
\text { - Initiatives such as ecoclubs and demonstrations for } \\
\text { treatment, care and maintenance of bednets } \\
\text { - School-based activities using the PLA approach } \\
\text { - User-friendly textbooks and manuals for both } \\
\text { - } \text { students and teachers } \\
\text { education and communication (IEC) materials }\end{array}$ & $\begin{array}{l}\text { Distribution of national and } \\
\text { international teaching and } \\
\text { IEC materials }\end{array}$ \\
\hline $\begin{array}{l}\text { Health } \\
\text { Research }\end{array}$ & & & $\begin{array}{l}\text { - Development of new drugs, insecticides, models of } \\
\text { disease epidemiology, vaccines and mosquito traps } \\
\text { - Epidemiological and entomological research on } \\
\text { malaria and dengue prevention and control }\end{array}$ & $\begin{array}{l}\text { - Research as a basis for } \\
\text { specific vector-borne } \\
\text { disease control measures } \\
\text { - Evaluation of the impact } \\
\text { of the use of impregnated } \\
\text { mosquito nets }\end{array}$ \\
\hline $\begin{array}{l}\text { Public Health } \\
\text { Measure }\end{array}$ & $\begin{array}{l}\text { - Active dengue } \\
\text { case findings by } \\
\text { family doctors }\end{array}$ & $\begin{array}{l}\text { - Provision of insecticide- } \\
\text { treated materials to } \\
\text { those who could not } \\
\text { afford them, courtesy of } \\
\text { the district health teams } \\
\text { and research groups } \\
\text { - Organization and } \\
\text { infrastructure of } \\
\text { cooperatives }\end{array}$ & $\begin{array}{l}\text { - Environmental modification and manipulation, risk } \\
\text { surveillance, and social mobilization } \\
\text { - Epidemiological methods such as mapping of } \\
\text { communities, rapid survey index, and the malaria } \\
\text { information system } \\
\text { - Multidisciplinary risk assessment and surveillance } \\
\text { system } \\
\text { - Interdepartmental collaboration for mosquito control } \\
\text { - } \text { program management and social mobilization } \\
\text { and community diagnosis }\end{array}$ & $\begin{array}{l}\text { - Reduction of taxes on } \\
\text { antimalarials } \\
\text { - Temporary lifting of the } \\
\text { ban on DDT for selective } \\
\text { residual house-spraying } \\
\text { - Collaboration and } \\
\text { creation of committees } \\
\text { and task forces for proper } \\
\text { management of programs } \\
\text { for VBD control }\end{array}$ \\
\hline $\begin{array}{l}\text { Resource } \\
\text { Mobilization }\end{array}$ & & & $\begin{array}{l}\text { - Funding from international donors for countries that } \\
\text { shifted to better insecticides, and the Global Fund for } \\
\text { the strengthening of local public health capacity } \\
\text { - Community self-sufficiency through alternative } \\
\text { income generating schemes and contributions } \\
\text { by municipalities }\end{array}$ & $\begin{array}{l}\text { Decentralization of the } \\
\text { malaria control program } \\
\text { - Establishment of a malaria } \\
\text { medicines and supply } \\
\text { service for procurement of } \\
\text { antimalarials } \\
\text { - International funding from } \\
\text { the Global Fund for shared } \\
\text { surveillance systems }\end{array}$ \\
\hline $\begin{array}{l}\text { Service } \\
\text { Delivery }\end{array}$ & & $\begin{array}{l}\text { - Efficient diagnostic methods } \\
\text { - More effective treatment } \\
\text { methods } \\
\text { - Inclusion of insecticide- } \\
\text { treated nets (ITNs) } \\
\text { and artemisinin-based } \\
\text { combination therapies } \\
\text { (ACTs) as major part of } \\
\text { program scale-up costs }\end{array}$ & $\begin{array}{l}\text { - Networks on malaria control in complex } \\
\text { emergencies, trained teachers involved in laboratory } \\
\text { diagnosis of malaria in children, and distribution of } \\
\text { synthetic antimalarials }\end{array}$ & $\begin{array}{l}\text { - Activities carried out } \\
\text { nationally and internationally } \\
\text { in cooperation with } \\
\text { stakeholders such as } \\
\text { the WHO } \\
\text { - Introduction of novel } \\
\text { combination therapies } \\
\text { recommended by WHO }\end{array}$ \\
\hline Training & $\begin{array}{l}\text { Collaborators } \\
\text { guided } \\
\text { householders to } \\
\text { practice simple } \\
\text { mosquito control } \\
\text { methods }\end{array}$ & $\begin{array}{l}\text { - Recruitment and support of } \\
\text { graduate and postgraduate } \\
\text { students in Africa for } \\
\text { research projects on malaria } \\
\text { and dengue }\end{array}$ & $\begin{array}{l}\text { - Training of teachers for school-based interventions, } \\
\text { and of health personnel for school health } \\
\text { management } \\
\text { - Training of locals for transition and sustainability of } \\
\text { control routines } \\
\text { - Community and field training for health professionals }\end{array}$ & $\begin{array}{l}\text { - Promotion by UN-FAO to } \\
\text { improve pest management } \\
\text { in environmentally benign } \\
\text { ways, empower farmers and } \\
\text { tap indigenous knowledge }\end{array}$ \\
\hline
\end{tabular}


Table 4. Goals, outputs and outcomes of ISCs for the prevention and control of VBDs

\begin{tabular}{|c|c|c|c|c|c|c|c|c|}
\hline & $\begin{array}{l}\text { Advocacy/ } \\
\text { Health } \\
\text { Promotion }\end{array}$ & $\begin{array}{l}\text { Health } \\
\text { Education }\end{array}$ & $\begin{array}{l}\text { Health } \\
\text { Research }\end{array}$ & $\begin{array}{l}\text { Public Health } \\
\text { Measure }\end{array}$ & $\begin{array}{l}\text { Resource } \\
\text { Mobilization }\end{array}$ & $\begin{array}{l}\text { Service } \\
\text { Delivery }\end{array}$ & Training & Collaboration \\
\hline $\begin{array}{l}\text { Goal } \\
\text { To reduce } \\
\text { the } \\
\text { morbidity } \\
\text { and } \\
\text { mortality } \\
\text { of vector- } \\
\text { borne } \\
\text { diseases }\end{array}$ & $\begin{array}{l}\text { To formulate } \\
\text { national } \\
\text { research } \\
\text { policies } \\
\text { oriented to } \\
\text { the solution } \\
\text { of national } \\
\text { problems }\end{array}$ & $\begin{array}{l}\text { To raise } \\
\text { awareness } \\
\text { of the } \\
\text { problem of } \\
\text { vector-borne } \\
\text { diseases } \\
\text { and how to } \\
\text { prevent and } \\
\text { control them }\end{array}$ & $\begin{array}{l}\text { To gather data } \\
\text { on vector- } \\
\text { borne diseases, } \\
\text { improve } \\
\text { surveillance, } \\
\text { and develop } \\
\text { tools and } \\
\text { strategies for } \\
\text { prevention and } \\
\text { control }\end{array}$ & $\begin{array}{l}\text { To implement } \\
\text { prevention } \\
\text { and control } \\
\text { strategies for } \\
\text { vector-borne } \\
\text { diseases }\end{array}$ & $\begin{array}{l}\text { To attract } \\
\text { additional } \\
\text { funding and } \\
\text { highlight } \\
\text { low-cost and } \\
\text { effective } \\
\text { interventions }\end{array}$ & $\begin{array}{l}\text { To provide } \\
\text { early } \\
\text { diagnosis } \\
\text { and prompt } \\
\text { treatment of } \\
\text { vector-borne } \\
\text { diseases }\end{array}$ & $\begin{array}{l}\text { To enhance } \\
\text { capacity of } \\
\text { personnel in } \\
\text { both health } \\
\text { and non-health } \\
\text { sectors for } \\
\text { successful } \\
\text { program } \\
\text { implementation }\end{array}$ & $\begin{array}{l}\text { To strengthen } \\
\text { coordination and } \\
\text { partnerships with } \\
\text { other sectors for } \\
\text { the prevention } \\
\text { and control of } \\
\text { vector-borne } \\
\text { diseases }\end{array}$ \\
\hline Output & $\begin{array}{l}\text { Publications, } \\
\text { community } \\
\text { road shows, } \\
\text { videos, and } \\
\text { documentaries } \\
\text { were used for } \\
\text { promotion. }\end{array}$ & $\begin{array}{l}\text { School } \\
\text { curricula } \\
\text { incorporated } \\
\text { vector } \\
\text { control, and } \\
\text { symposia } \\
\text { were held } \\
\text { to build } \\
\text { networks. }\end{array}$ & $\begin{array}{l}\text { Research } \\
\text { for the } \\
\text { development } \\
\text { of new } \\
\text { approaches } \\
\text { to vector } \\
\text { and disease } \\
\text { control were } \\
\text { conducted and } \\
\text { encouraged. }\end{array}$ & $\begin{array}{l}\text { ITNs, larvicide } \\
\text { treatment, } \\
\text { mesocyclops, } \\
\text { and new } \\
\text { technology } \\
\text { for monitoring } \\
\text { were } \\
\text { frequently } \\
\text { used. }\end{array}$ & $\begin{array}{l}\text { Most of the } \\
\text { funds used } \\
\text { in these ISCs } \\
\text { were obtained } \\
\text { from other } \\
\text { organizations. }\end{array}$ & $\begin{array}{l}\text { Doctors } \\
\text { were } \\
\text { deployed } \\
\text { to malaria- } \\
\text { endemic } \\
\text { countries } \\
\text { and } \\
\text { antimalarial } \\
\text { drugs were } \\
\text { distributed. }\end{array}$ & $\begin{array}{l}\text { Training } \\
\text { workshops } \\
\text { were held for } \\
\text { technical staff } \\
\text { and health } \\
\text { professionals to } \\
\text { broaden their } \\
\text { knowledge } \\
\text { about VBDs. }\end{array}$ & $\begin{array}{l}\text { More vector } \\
\text { control } \\
\text { committees were } \\
\text { created, and } \\
\text { projects were } \\
\text { expanded. }\end{array}$ \\
\hline $\begin{array}{l}\text { Outcome/ } \\
\text { Impact }\end{array}$ & $\begin{array}{l}\text { Awareness } \\
\text { about VBDs } \\
\text { was raised in } \\
\text { the involved } \\
\text { communities. } \\
\text { As a result of } \\
\text { intersectoral } \\
\text { coordination, } \\
\text { the number } \\
\text { of activities } \\
\text { for prevention } \\
\text { and control } \\
\text { and creation } \\
\text { of public } \\
\text { awareness } \\
\text { increased. }\end{array}$ & $\begin{array}{l}\text { Both children } \\
\text { and adults } \\
\text { showed } \\
\text { significant } \\
\text { improvements } \\
\text { in their } \\
\text { knowledge } \\
\text { on vector } \\
\text { control. } \\
\text { There was } \\
\text { more active } \\
\text { participation } \\
\text { in prevention } \\
\text { and control } \\
\text { efforts by the } \\
\text { community. }\end{array}$ & $\begin{array}{l}\text { Research } \\
\text { leadership } \\
\text { especially in } \\
\text { Africa was } \\
\text { enhanced } \\
\text { by various } \\
\text { programs for } \\
\text { the prevention } \\
\text { and control of } \\
\text { malaria. Multi- } \\
\text { center research } \\
\text { networks and } \\
\text { projects for the } \\
\text { prevention of } \\
\text { VBDs resulted } \\
\text { from the } \\
\text { collaborations. }\end{array}$ & $\begin{array}{l}\text { Malaria and } \\
\text { dengue } \\
\text { incidence and } \\
\text { prevalence } \\
\text { markedly } \\
\text { declined. The } \\
\text { mosquito } \\
\text { vectors } \\
\text { were either } \\
\text { eliminated } \\
\text { or greatly } \\
\text { reduced } \\
\text { through } \\
\text { community } \\
\text { participation } \\
\text { in the } \\
\text { prevention } \\
\text { measures. }\end{array}$ & $\begin{array}{l}\text { Intersectoral } \\
\text { collaborations } \\
\text { encouraged } \\
\text { project } \\
\text { funding } \\
\text { by and } \\
\text { participation } \\
\text { of different } \\
\text { institutions. } \\
\text { The } \\
\text { availability and } \\
\text { capabilities } \\
\text { of human } \\
\text { resources for } \\
\text { health in the } \\
\text { communities } \\
\text { also increased. }\end{array}$ & $\begin{array}{l}\text { Compliance } \\
\text { with } \\
\text { treatment } \\
\text { for malaria } \\
\text { and dengue } \\
\text { increased. }\end{array}$ & $\begin{array}{l}\text { Control } \\
\text { programs gained } \\
\text { partners such as } \\
\text { school teachers } \\
\text { and community } \\
\text { volunteers } \\
\text { to aid in } \\
\text { implementation } \\
\text { of activities. The } \\
\text { employment } \\
\text { rate of the } \\
\text { community } \\
\text { workers } \\
\text { involved in the } \\
\text { prevention } \\
\text { activities } \\
\text { increased. }\end{array}$ & $\begin{array}{l}\text { The number of } \\
\text { stakeholders } \\
\text { engaged in } \\
\text { the programs } \\
\text { increased, } \\
\text { making project } \\
\text { implementation } \\
\text { easier. } \\
\text { Sustainability } \\
\text { showed marked } \\
\text { improvement, } \\
\text { and activities } \\
\text { were expanded } \\
\text { to other areas } \\
\text { as a result of the } \\
\text { increased interest } \\
\text { of community } \\
\text { leaders. }\end{array}$ \\
\hline
\end{tabular}

\section{Gaps}

The problems or gaps encountered in the planning and implementation of the prevention and control programs were categorized into the following: administrative, resource, policy, research, and training/capacity building (Table 5). They were further classified as either antecedent or mediating conditions. Antecedent factors are the conditions present before implementation began, such as environmental characteristics and innate skills and values of community members, while mediating factors are those that occur during the implementation proper, such as staff turnover or withdrawal of financial support. ${ }^{79}$

\section{DISCUSSION AND CONCLUSION}

To the best of the authors' knowledge, this review is the first to synthesize evidence for models of intersectoral collaborations specifically for vector-borne diseases. The comprehensive strategies support the stand of the
Multisectoral Action Framework for Malaria on how very few (if any) social and environmental determinants of the disease are the sole responsibility of a single sector, particularly the health sector. Most of the articles discussed intersectoral approaches for the prevention of malaria and were also concentrated in the African region. Studies that discussed approaches for the prevention and control of dengue, on the other hand, amounted to less than half of the articles included in this review. Less than half of the articles talked about interventions based in Asia and Latin America, where dengue is a leading cause of child morbidity and mortality.

There were many gaps or challenges that impeded successful implementation and lowered chances of project sustainability, most notably the disconnection between stakeholder responsibilities. The observation that there is a lack of communication between multilateral organizations and local governments is of great concern, because nearly all studies included in this review had multilateral organizations as their proponents, while no studies were initiated by 
Table 5. Gaps encountered by ISC

\begin{tabular}{|c|c|c|c|c|c|}
\hline & Administrative & Resource & Policy & Research & Training \\
\hline Antecedent & $\begin{array}{l}\text { Sustainability } \\
\text { - Poor quality } \\
\text { infrastructure } \\
\text { and inappropriate } \\
\text { systems } \\
\text { - Lack of initiative } \\
\text { and interest } \\
\text { of donors and } \\
\text { stakeholders } \\
\text { regarding the issue } \\
\text { Implementation } \\
\text { - Disconnected } \\
\text { intersectoral/ } \\
\text { inter-stakeholder } \\
\text { relationships } \\
\text { - Lack of consultation } \\
\text { in planning; Lack of } \\
\text { robust strategies }\end{array}$ & $\begin{array}{l}\text { Sustainability } \\
\text { - Lack of } \\
\text { human } \\
\text { resource } \\
\text { development, } \\
\text { increased } \\
\text { migration, and } \\
\text { increased staff } \\
\text { turnover } \\
\text { - Lack of } \\
\text { funding due } \\
\text { to global } \\
\text { economic crisis } \\
\text { - Inadequate } \\
\text { facilities and } \\
\text { equipment for } \\
\text { diagnosis and } \\
\text { treatment } \\
\text { - Lack of } \\
\text { technical } \\
\text { support from } \\
\text { multilateral } \\
\text { organizations } \\
\text { Accessibility } \\
\text { - Geographical } \\
\text { barriers } \\
\text { - Logistical } \\
\text { barriers such as } \\
\text { lack of vehicles, } \\
\text { drugs, ITNs }\end{array}$ & $\begin{array}{l}\text { Accessibility } \\
\text { - Taxation, increased costs } \\
\text { due to import taxes and VAT } \\
\text { - Uneven competitive field } \\
\text { between locally-produced } \\
\text { nets and imported nets } \\
\text { - Existing principles for the } \\
\text { handling of foreign currency } \\
\text { contradictory to provisions in } \\
\text { the grant proposal } \\
\text { Implementation } \\
\text { - Unclear policies on role of } \\
\text { voluntary health workers } \\
\text { - Lack of an overarching } \\
\text { strategic vision for GFATM } \\
\text { - Donors' lack of confidence } \\
\text { in the proponents and in the } \\
\text { feasibility of the program } \\
\text { - Globalization-from-above } \\
\text { accompanied by a lack of } \\
\text { accountability } \\
\text { - Stifling political } \\
\text { environment } \\
\text { - Policy-culture mismatch, } \\
\text { i.e. government attempts to } \\
\text { promote indoor mosquito } \\
\text { nets failed because residents } \\
\text { would sleep outdoors. }\end{array}$ & $\begin{array}{l}\text { Availability of Data } \\
\text { - Lack of accurate } \\
\text { epidemiological data } \\
\text { and data on donor } \\
\text { support for program } \\
\text { planning } \\
\text { - Hesitation to disclose } \\
\text { data on malaria control } \\
\text { funding } \\
\text { - Scarcity of research } \\
\text { capacity } \\
\text { Geographical Barriers } \\
\text { - Difficult terrain } \\
\text { and geographical } \\
\text { complexity } \\
\text { - Unsuitability of } \\
\text { existing models to } \\
\text { target regions } \\
\text { Research Methods } \\
\text { - No available } \\
\text { techniques for data } \\
\text { analysis } \\
\text { - Difficulty in } \\
\text { measuring mortality } \\
\text { and other variables } \\
\text { - Absence of an } \\
\text { internal control arm } \\
\text { in a before-and- } \\
\text { after community } \\
\text { intervention leading to } \\
\text { limited interpretation } \\
\text { of results }\end{array}$ & $\begin{array}{l}\text { Preexisting levels of comprehension, } \\
\text { knowledge, and skills } \\
\text { - Low levels of English } \\
\text { competency leading to difficulty in } \\
\text { comprehending technical matters } \\
\text { - Different levels of knowledge } \\
\text { and skills among trainees within } \\
\text { the same sector and between } \\
\text { different sectors (such as health vs } \\
\text { education) } \\
\text { - Difficulty in adopting an } \\
\text { intersectoral mindset and systems- } \\
\text { level thinking } \\
\text { - Shortage of skilled and } \\
\text { knowledgeable staff } \\
\text { - Inadequate local capacity for } \\
\text { malaria control } \\
\text { Training mechanisms and priorities } \\
\text { - Inadequate training, insufficient } \\
\text { logistic support, poorly sustained } \\
\text { motivation schemes, and lack of } \\
\text { community support } \\
\text { - No expert training (or access to } \\
\text { current training material relating to } \\
\text { mosquito abatement) for existing } \\
\text { municipal health teams leading } \\
\text { to poor standards of training } \\
\text { and practice } \\
\text { - Poor or absence of training on } \\
\text { malaria in pre-service curricula } \\
\text { for schools of medicine, nursing, } \\
\text { pharmacy, and laboratory } \\
\text { technology }\end{array}$ \\
\hline Mediating & $\begin{array}{l}\text { Sustainability } \\
\text { Lack of facilitation, } \\
\text { continuity, and } \\
\text { sustained community } \\
\text { participation } \\
\text { Implementation } \\
\text { - Insufficient } \\
\text { monitoring and } \\
\text { supervision } \\
\text { - Limited source } \\
\text { reduction efforts } \\
\text { - Delays in service } \\
\text { delivery due to fears } \\
\text { of staff } \\
\text { - Work overload due } \\
\text { to change in system; } \\
\text { disparities in salary } \\
\text { levels between } \\
\text { field workers and } \\
\text { municipal-level } \\
\text { officers } \\
\text { - Neglect of the role } \\
\text { of epidemiology in } \\
\text { prevention activities }\end{array}$ & $\begin{array}{l}\text { Sustainability } \\
\text { - Misuse and } \\
\text { discontinuity of } \\
\text { funds } \\
\text { - Difficulty in } \\
\text { recruiting and } \\
\text { retaining health } \\
\text { professionals } \\
\text { - Fluctuations } \\
\text { in electrical, } \\
\text { water, fuel and } \\
\text { IT services; lack } \\
\text { of sustained } \\
\text { political } \\
\text { support } \\
\text { Accessibility } \\
\text { - Inaccessibility } \\
\text { of ACTs and } \\
\text { ITNs; } \\
\text { - Insufficient } \\
\text { and } \\
\text { discontinuous } \\
\text { supply of } \\
\text { insecticides }\end{array}$ & $\begin{array}{l}\text { Accessibility } \\
\text { - Economic barriers, such as } \\
\text { price hikes implemented by } \\
\text { shopkeepers in response to } \\
\text { discounts laid in place by the } \\
\text { prevention/control program } \\
\text { - Re-introduction of taxes } \\
\text { and tariffs on mosquito net } \\
\text { products for the generation } \\
\text { of internal revenue } \\
\text { Implementation } \\
\text { - Poor implementation of } \\
\text { prevention and treatment } \\
\text { guidelines in both public and } \\
\text { private sectors } \\
\text { - Disagreements between } \\
\text { sectors, i.e. recommendations } \\
\text { by multilateral organizations } \\
\text { were deemed unnecessary by } \\
\text { some malariologists } \\
\text { - Malaria patients refused } \\
\text { treatment or pretended } \\
\text { to take the drugs but sold } \\
\text { them instead }\end{array}$ & $\begin{array}{l}\text { Research Methods } \\
\text { - Incomplete data due } \\
\text { to irregular collection } \\
\text { of slides } \\
\text { - Failure to address the } \\
\text { effects of clustering } \\
\text { - Possible } \\
\text { underestimation of the } \\
\text { effectiveness of the } \\
\text { interventions }\end{array}$ & $\begin{array}{l}\text { Sustainability } \\
\text { - Insufficient development of } \\
\text { national ownership and capacity } \\
\text { - Failure to provide a } \\
\text { comprehensive and suitable } \\
\text { training course for community } \\
\text { members } \\
\text { Implementation and Performance } \\
\text { Management } \\
\text { - Lack of cooperation with and } \\
\text { comprehension of the training } \\
\text { method }\end{array}$ \\
\hline
\end{tabular}


community members. This top-down approach makes stakeholder relationships more susceptible to disconnect, highlighted also by several instances wherein projects would not be sustained by local governments after departure of the representatives of multilateral proponents; in the case of $\mathrm{RBM}$, despite the formation of a steering committee, there was a lack of facilitation after the departure of the RBM support officer. Ownership of the programs by the community was an issue, as multiple cases cited the lack of understanding, interest, and initiative as a reason for discontinuity.

A lack of research capacity, including baseline data, skilled and knowledgeable staff, and models for data analysis that could be contextualized to studies done in local communities, was evident for both malaria and dengue control programs. Without baseline epidemiological, entomological, and demographic data, plans for the development of vector control programs would not be effective and fit to the local community. Baseline data could be produced only with the availability of skilled and knowledgeable staff - another identified gap. Low levels of English competency, inadequate skills in data collection, management, and implementation of malaria control, and a difficulty in looking beyond the disease itself for health professionals were all pre-existing challenges in capacity building and implementation of vector borne disease control programs. These challenges highlighted the need for a more intersectoral mindset in approaching disease prevention and control. The lack of research capacity and the inability to train local staff to address this problem contributed to the issues of dengue case under-reporting and misclassification.

Like other literature reviews, the results of this scoping review were dependent on the availability of information on the review question - in this case, existing models of inter-sectoral collaborations for the prevention and control of vector-borne diseases. Due to time constraints, foreign language articles were not included, no hand searching was done, and only three vector borne diseases were included in the scoping review: dengue, malaria, and yellow fever. However, there were no articles that discussed yellow fever deemed to be relevant to the research question or that discussed inter-sectoral collaborations for the prevention of yellow fever in detail. Additionally, only articles published between 1985 and 2016 were included, and so the publications on the Eliminate Yellow Fever Epidemics (EYE) Strategy that were published in early 2017 were not included despite having discussed intersectoral collaborations to some extent. ${ }^{80}$

In spite of these challenges and limitations, the results show the comprehensive framework needed for an effective and sustainable multi-sectoral approach to the prevention and control of vector borne diseases. Before a vector-borne disease control program may be rolled out, adequate resources must be secured. All stakeholders must actively participate from the planning phase (one identified gap was the lack of consultation among stakeholders in program planning). Stakeholders include academe and research institutes, civil society organizations, communities, ministries of health, government agencies (especially the education and agriculture sectors), industries, and multilateral organizations. Sustainable funding must be ensured through the cooperation of all stakeholders and the active engagement of the community, as a major challenge identified was the decrease in foreign aid from other countries and from multilateral organizations. Strategies must be comprehensive and be employed throughout the entire socio-ecological spectrum - from an individual level, to organizational processes and systems, to community level interactions, and to policies and entire systems. Strategies include advocacy and health promotion, health education, health research, public health measures, resource mobilization, service delivery or provision, training and capacity building, and an overarching effort to collaborate with one another.

In conclusion, this review shows that an ideal approach for the prevention and control of VBDs includes a collaboration among active stakeholders to deliver effective strategies including but not limited to health education and public health measures. Community involvement through training and capacity building ensures the sustainability of the interventions.

As both intersectoral collaboration and vector-borne diseases are broad topics that hinge on social and economic development, future research may delve deeper into issues of financing, investment in human resource development for, and supply and demand of ITNs and drugs for such programs by conducting economic evaluations including but not limited to cost utility analyses and labor market analyses. The lack of financial resources and of human resources were identified as factors that blocked sustainability and limited effectiveness of the interventions. Scoping reviews on similar topics may also consider wider time frames, given the high yield of articles from this particular area of research and given the nature of a scoping review in itself.

\section{Statement of Authorship}

CTA conceptualized the scoping review; CTA, ACB, KLC, EAR and MSS contributed and approved the design. MLR, CHT and CTA prepared the draft publishable manuscript, and prepared the responses to reviewers' comments. All authors participated in data collection and analysis, and approved the final version submitted.

\section{Author Disclosure}

All authors declared no conflict of interest.

\section{Funding Source}

This commissioned review was supported by TDR, the Special Programme for Research and Training in Tropical Diseases, and International Development Research Centre (Contract No. 301713). 


\section{REFERENCES}

1. WHO-TDR. Call for applications: Institutions and/or consultants to perform commissioned reviews on multi-sectoral approaches for the prevention and control of malaria and emerging arboviral diseases [Internet]. 2017. Available from: http://www.who.int/tdr/grants/calls/ MSA-Call-Jan2017.pdf?ua $=1$.

2. World Health Organization. World Malaria Report 2017 [Internet]. Geneva; Available from: http://apps.who.int/iris/bitstream/hand le/10665/259492/9789241565523-eng.pdf;jsessionid=10085BCB02B 30DB994FAC173D1EBCAD0? sequence $=1$.

3. Stanaway JD, Shepard DS, Undurraga EA, Halasa YA, Coffeng LE, Brady OJ, Hay SI, Bedi N, Bensenor IM, Castañeda-Orjuela CA, Chuang T-W, Gibney KB, Memish ZA, Rafay A, Ukwaja KN, Yonemoto N, Murray CJL. The global burden of dengue: an analysis from the Global Burden of Disease Study 2013. Lancet Infect Dis [Internet]. Elsevier; 2016 Jun 1 [cited 2018 Mar 26];16(6):712-3. Available from: http://www.ncbi.nlm.nih.gov/pubmed/26874619 PMID: 26874619

4. Blas E. Multisectoral Action Framework for Malaria [Internet]. UNDP and RBM; 2013 [cited 2018 Mar 26]. Available from: http:// www.rollbackmalaria.org/files/files/about/MultisectoralApproach/ Multisectoral-Action-Framework-for-Malaria.pdf.

5. World Health Organization. WHO | Neglected tropical diseases Integrated Vector Management (IVM) [Internet]. Neglected tropical diseases. World Health Organization; 2011. Available from: http:// www.who.int/neglected_diseases/vector_ecology/ivm_concept/en/.

6. Arksey H, O'Malley L. Scoping studies: towards a methodological framework. Int J Soc Res Methodol [Internet]. Taylor and Francis Group Ltd; 2005 Feb [cited 2018 Mar 26];8(1):19-32. Available from: http://www.tandfonline.com/doi/abs/10.1080/1364557032000119616.

7. Levac D, Colquhoun H, O'Brien KK. Scoping studies: advancing the methodology. Implement Sci [Internet]. BioMed Central; 2010 Dec 20 [cited 2018 Mar 26];5(1):69. Available from: http://implementationscience.biomedcentral.com/articles/10.1186/ 1748-5908-5-69.

8. Peters M, Godfrey C, McInerney P, Soares C, Khalil H, Parker D. The Joanna Briggs Institute Reviewers' Manual 2015: Methodology for JBI Scoping Reviews [Internet]. The Joanna Briggs Institute; 2015. Available from: https://joannabriggs.org/assets/ docs/sumari/ Reviewers-Manual_Methodology-for-JBI-Scoping-Reviews_2015_ v2.pdf.

9. Colquhoun HL, Levac D, O'Brien KK, Straus S, Tricco AC, Perrier L, Kastner M, Moher D. Scoping reviews: Time for clarity in definition, methods, and reporting [Internet]. Journal of Clinical Epidemiology. 2014 [cited 2018 Apr 4]. pp. 1291-4. Available from: http://www.ncbi. nlm.nih.gov/pubmed/25034198 PMID: 25034198.

10. Alvarez A. Malaria and the emergence of rural health in Argentina: an analysis from the perspective of international interaction and co-operation. Can Bull Med Hist. 2008;25(1):137-60.

11. Gerrets RP. Globalizing international health: The cultural politics of 'partnership' in Tanzanian malaria control. Department of Anthropology. [ProQuest Dissertations Publishing]: New York University; 2010.

12. Mukabana W, Kannady K, Kiama G, Ijumba J, Mathenge E, Kiche I, Nkwengulila G, Mboera L, Mtasiwa D, Yamagata Y, Van Schayk I, Knols B, Lindsay S, De Castro C, Mshinda H, Tanner M, Fillinger U, Killeen G. Ecologists can enable communities to implement malaria vector control in Africa. Malar J [Internet]. 2006;5(9). Available from: https://malariajournal.biomedcentral.com/ articles/10.1186/1475-2875-5-9 PMID: 16457724.

13. Gürtler RE, Garelli FM, Coto HD. Effects of a five-year citywide intervention program to control Aedes aegypti and prevent dengue outbreaks in Northern Argentina. PLoS Negl Trop Dis. 2009; 3(4):e427.

14. Breman JG, Greenwood B, Druilhe P, Nabarro D, Mendis K, Kilama WL. Rolling back malaria: Action or rhetoric? Bull World Health Organ. 2000;78(12):1450-5.
15. Taylor EM, Harper I. The politics and anti-politics of the global fund experiment: understanding partnership and bureaucratic expansion in Uganda. Med Anthropol. 2014;33(3):206-22.

16. Hu T, Liu YB, Zhang SS, Xia ZG, Zhou SS, Yan J, et al. Shrinking the malaria map in China: measuring the progress of the National Malaria Elimination Programme. Infect Dis Poverty. 2016 May; 5(1):52.

17. Townson H, Nathan MN, Zaim M, Guillet P, Manga L, Bos R, Kindhauser M. Exploiting the potential of vector control for disease prevention. Bull World Health Organ [Internet]. 2005;83(12):942-7. Available from: https://www.ncbi.nlm.nih.gov/ pubmed/16462987

18. Kolaczinski J. Roll Back Malaria in the aftermath of complex emergencies: The example of Afghanistan. Trop Med Int Health. 2005 Sep;10(9):888-93.

19. Griffing SM, Tauil PL, Udhayakumar V, Silva-Flannery L, A historical perspective on malaria control in Brazil. Mem Inst Oswaldo Cruz. 2015 Sep; 110(6):701-18.

20. Toledo ME, Vanlerberghe V, Baly A, Ceballos E, Valdes L, Searret $\mathrm{M}$, et al. Towards active community participation in dengue vector control: results from action research in Santiago de Cuba, Cuba. Trans R Soc Trop Med Hyg. 2007 Jan; 101(1):56-63.

21. Pan American Health Organization - World Health Organization. Integrated Management Strategy for Dengue Prevention and Control in the Caribbean Subregion. Integrated Management Strategy for Dengue Prevention and Control (IMS-Dengue). Washington, D.C. 20037.

22. Johns Hopkins Center for Communication Programs. Strategic Framework for Malaria Communication at the Country Level [Internet]. Baltimore, MD 21202: The Johns Hopkins University; 2012. Available from: https://ccp.jhu.edu/2012/09/05/ strategic-frameworkfor-malaria-communication-at-the-country-level-is-launched/.

23. Xia ZG, Wang RB, Wang DQ, Feng J, Zheng Q, Deng CS. ChinaAfrica cooperation initiatives in malaria control and elimination. Adv Parasitol. 2014;86:319-37.

24. Newby G, Bennet A, Larson E, Cotter C, Shretta R, Phillips AA, et al. The path to eradication: a progress report on the malaria-eliminating countries. Lancet. 2016 Apr; 387(10029):1775-84.

25. Mutero CM, Mbogo C, Mwangangi J, Imbahale S, Kibe L, Orindi $\mathrm{B}$, et al. An assessment of participatory integrated vector management for malaria control in Kenya. Environ Health Perspect. 2015 Nov;123(11):1145-51.

26. First ASEAN Dengue Day Marks the Need for Continued Vigilance on Dengue Control and International Cooperation Singapore Government News New Delhi. Singapore Gov News. New Delhi: Athena Information Solutions Pvt. Ltd.; 2011.

27. Chaki PP, Mtasiwa D, Tanner M, Mshinda H, Kelly AH, Killeen GF, Kannady K. Institutional evolution of a community-based programme for malaria control through larval source management in Dar es Salaam, United Republic of Tanzania. Malar J [Internet]. 2014;13(245). Available from: http://www.malariajournal.com/ content/ 13/1/245

28. Ayi I, Adjovu JK, Hanafusa S, Jimba M, Bosompem KM, Mizoue T, Takeuchi T, Boakye DA, Kobayashi J, Nonaka D. School-based participatory health education for malaria control in Ghana: engaging children as health messengers. Malar J [Internet]. 2010;9. Available from: http://www.malariajournal.com/content/9/1/98

29. Ceccato P, Connor SJ, Jeanne I, Thomson MC. Application of Geographical Information Systems and Remote Sensing technologies for assessing and monitoring malaria risk. Parassitologia. 2005 Mar; 47(1):81-96.

30. Rugemalila JB, Ogundahunsi OAT, Stedman TT, Kilama WL. Multilateral initiative on malaria: justification, evolution, achievements, challenges, opportunities, and future plans. Am J Trop Med Hyg. 2007 Dec; 77(6 Suppl):296-302.

31. Nafo-Traoré F. Rolling back malaria: Opportunities and challenges. Trans R Soc Trop Med Hyg. 2005 Jun; 99(6):403-6.

32. Sanchez L, Perez D, Cruz G, Castro M, Kourí G, Shkedy Z, et al. Intersectoral coordination, community empowerment and dengue prevention: Six years of controlled interventions in Playa municipality, Havana, Cuba. Trop Med Int Health. 2009 Nov; 14(11):1356-64. 
33. Najera JA \& Global Partnership to Roll Back Malaria. Malaria control: achievements, problems and strategies [Internet]. Geneva: World Health Organization; 1999. Available from: http://www.who.int/iris/ handle/10665/66640.

34. Bradley DJ. Malaria in Africa - Ecohealth Projects. Canada: International Development Research Centre; 2007.

35. Njau RJ, de Savigny D, Gilson L, Mwageni E, Mosha FW. Implementation of an insecticide-treated net subsidy scheme under a public-private partnership for malaria control in Tanzania - challenges in implementation. Malar J. 2009 Aug; 8:201.

36. Chanda E, Masaninga F, Coleman M, Sikaala C, Katebe C, MacDonald M, Baboo KS, Govere J, Manga L. Integrated vector management: The Zambian experience. Malar J [Internet]. 2008;7(1 LB-Chanda2008):164. Available from: https://doi.org/ $10.1186 / 1475-2875-7-164$.

37. Reversing the failures of Roll Back Malaria. Lancet. 2005 Apr; 365(9469):1439.

38. Marsh VM, Mutemi W, Some ES, Haaland A, Snow RW. Evaluating the community education programme of an insecticide-treated bed net trial on the Kenyan coast. Health Policy Plan [Internet]. 1996 Sep; 11(3):280-91.

39. Kojima S, Aoki Y, Ohta N, Tateno S, Takeuchi T. School-health-based parasite control initiatives: extending successful Japanese policies to Asia and Africa. Trends Parasitol. 2007 Feb; 23(2):54-7.

40. Rojas W, Botero S, Garcia HI. An integrated malaria control program with community participation on the Pacific Coast of Colombia. Cad Saude Publica. 2001;17 Suppl:103-13.

41. Campbell CC. Halting the toll of malaria in Africa. Am J Trop Med Hyg. 2008 Jun; 78(6):851-3.

42. Nonaka D, Kobayashi J, Jimba M, Vilaysouk B, Tsukamoto K, Kano $\mathrm{S}$, et al. Malaria education from school to community in Oudomxay province, Lao PDR. Parasitol Int. 2008 Mar; 57(1):76-82.

43. Lin H, Liu T, Song T, Lin L, Xiao J, Lin J, et al. Community Involvement in Dengue Outbreak Control: An Integrated Rigorous Intervention Strategy. PLoS Neg1 Trop Dis. 2016 Aug; 10(8):e0004919.

44. Fitzpatrick J, Ako WY. Empowering the initiation of a prevention strategy to combat malaria in Papua New Guinea. Rural Remote Health [Internet]. 2007;7(2):693. Available from: http://www.rrh. org.au/journal/article/693.

45. World Health Organization. Global malaria control strategy. 1993;280-3.

46. Litsios S. Malaria control, the cold war, and the postwar reorganization of international assistance. Med Anthropol. 1997 May; 17(3):255-78.

47. Kroeger A, Ordoñnez-GonzalezJ, Escandon C, Aviñna A. Community cooperatives and insecticide-treated materials for malaria control: a new experience in Latin America. Malar J [Internet]. 2002;1(15). Available from: http://www.malariajournal.com/content/1/1/15.

48. Lloyd LS. Best Practices for Dengue Control and Prevention in the Americas. Project EH, editor. Strategic Report. 2003.

49. Attaran A. Where did it all go wrong? Nature. 2004 Aug; 430(7002):932-3.

50. Sanders KC, Jelip J, Rashman Y, Gueye CS, Gosling RD, Rundi C. Eliminating malaria in Malaysia: The role of partnerships between the public and commercial sectors in Sabah. Malar J [Internet]. 2014;13(24). Available from: http://www.malariajournal.com/content/ $13 / 1 / 24$

51. Sedlmayr R, Miller JM, Earle D, Steketee RW, Fink G. Health impact and cost-effectiveness of a private sector bed net distribution: Experimental evidence from Zambia. Malar J [Internet]. 2013;12(1). Available from: http://www.malariajournal.com/content/12/1/102.

52. Thailand: Thailand hosts training course for African malaria control Asia News Monitor Bangkok. Asia News Monit Bangkok. Bangkok, Thailand: Thai News Service Group.

53. Herrera S, Ochoa-Orozco SA, González IJ, Peinado L, Quiñones ML, Arévalo-Herrera M. Prospects for Malaria Elimination in Mesoamerica and Hispaniola. PLoS Negl Trop Dis. 2015 May; 9(5): $\mathrm{e} 0003700$.

54. Alnwick D. Roll back malaria - What are the prospects? Bull World Health Organ. 2000;78(12):1377.
55. De Castro MC, Yamagata Y, Mtasiwa D, Tanner M, Utzinger J, Keiser J, Singer BH. Integrated Urban Malaria Control: A Case Study in Dar Es Salaam, Tanzania. Am J Trop Med Hyg [Internet]. 2004;71(2 Suppl):103-17. Available from: https://www.ncbi.nlm.nih.gov/books/ NBK3748/

56. Hochman G. From autonomy to partial alignment: national malaria programs in the time of global eradication, Brazil, 1941-1961. Can Bull Med Hist. 2008;25(1):161-92.

57. Aginam O. From the core to the peripheries: multilateral governance of malaria in a multi-cultural world. Chic J Int Law. 2002;3(1):87-103.

58. Heddini A, Keusch GT, Davies CS. The multilateral initiative on malaria: Past, present, and future. Am J Trop Med Hyg. 2004 Aug; 71(2 Suppl):279-82.

59. Tissera H, Samaraweera $P$, Weeraman J, Palihawadana $P$, Amarasinghe A, Pannila-Hetti N. Sustainable dengue prevention and control through a comprehensive integrated approach: the Sri Lankan perspective. WHO South-East Asia J Public Health. 2016 Sep; 5(2):106-12.

60. Afenyadu GY, Agyepong IA, Barnish G, Adjei S. Improving access to early treatment of malaria: a trial with primary school teachers as care providers. Trop Med Int Health. 2005 Oct;10(10):1065-72.

61. Kant R, Srivastava HC, Sharma VP, Haq S. Review of the bioenvironmental methods for malaria control with special reference to the use of larvivorous fishes and composite fish culture in central Gujarat, India. J Vector Borne Dis [Internet]. 2013;50(1):1-12. Available from: https://www.ncbi.nlm.nih.gov/pubmed/23703433.

62. Coll-Seck AM. Hopes and fears for malaria. Bull World Health Organ. 2008 Feb; 86(2):91-2.

63. Nam VS, Phong TV, Ninh TU, Mai LQ, Lo LV, Nghia LT, Bektas A, Briscombe A, Aaskov JG, Ryan PA, Kay BH, Yen NT. Elimination of dengue by community programs using Mesocyclops(Copepoda) against Aedes aegypti in central Vietnam. Am J Trop Med Hyg [Internet]. 2005;72(1):67-73. Available from: https://www.ncbi.nlm. nih.gov/pubmed/15728869.

64. Lima EC, Vilasbôas AL. Inter-sector social mobilization for dengue control in Bahia State, Brazil. Cad Saude Publica. 2011 Aug; 27(8):1507-19.

65. Mboera LEG, Mukabana WR, Njunwa KJ, Kabbale F. Integrated Research Partnerships for Malaria Control through an Ecohealth Approach in East Africa: Kenya, Rwanda, Tanzania and Uganda Projects [Internet]. Dar es Salaam, Tanzania; 2014. Available from: http://hdl.handle.net/10625/52443.

66. Kuratsuji T. The joint JMA-JICA project in Nepal. Acta Paediatr Jpn. 1993 Dec; 35(6):571-5.

67. Magnussen P, Ndawi B, Sheshe AK, Byskov J, Mbwana K. Malaria diagnosis and treatment administered by teachers in primary schools in Tanzania. Trop Med Int Health. 2001 Apr; 6(4):273-9.

68. Teklehaimanot A, Keusch G , Binder S. Malaria. Emerg Infect Dis. 2001;7(3 Suppl):546-7.

69. Global Partnership to Roll Back Malaria, World Health Organization - Regional Office for the Western Pacific, World Health Organization - Regional Office for South-East Asia. Planning meeting for the implementation of Roll Back Malaria in the six Mekong countries, Ho Chi Minh City, Viet Nam, 2-4 March 1999. Geneva: World Health Organization; 2000.

70. Okabayashi H, Thongthien P, Singhasvanon P, Wikagul J, Looareesuwan S, Jimba M, et al. Keys to success for a school-based malaria control program in primary schools in Thailand. Parasitol Int. 2006 Jun; 55(2):121-6.

71. Kojima S, Looareesuwan S, Singhasivanon P, Takeuchi T. The Asian center of international parasite control (ACIPAC): five years of achievement. Southeast Asian J Trop Med Public Health. 2005; 36(Suppl 3):1-12.

72. Infectious Disease; CIRAD, Institut Pasteur and IRD partners in research on emerging vector-borne diseases. TB Outbreaks Week. Atlanta: NewsRx; 2002;11.

73. World Health Organization. Roll back malaria - progress report (Part II). Wkly Epidemiol Rec. 2001;76(12):89-91. 
74. DaSilva J, Garanganga B, Teveredzi V, Marx SM, Mason SJ, Connor SJ. Improving epidemic malaria planning, preparedness and response in Southern Africa. Malar J. 2004 Oct;3:37.

75. Bates N, Herrington J. Advocacy for malaria prevention, control, and research in the twenty-first century. Am J Trop Med Hyg. 2007 Dec; 77(6 Suppl):314-20.

76. Litsios S. Intersectoral collaboration for the promotion of primary health care-based vector control: Considerations related to malaria. World Health Organization; 1987.

77. International Development Research Centre, WHO Special Programme for Research and Training in Tropical Diseases. Ecohealth Approaches to the Prevention and Control of Vector-Borne Diseases in Africa, Asia and Latin America and the Caribbean: Inter-regional Dialogue and Exchange. 2008.
78. San Martin JL, Brathwaite-Dick O. Delivery Issues Related To Vector Control Operations: A Special Focus On The Americas. Scientific Working Group, Report on Dengue. Geneva, Switzerland: Regional Dengue Program, Pan American Health Organization/World Health Organization, Regional Office for Dengue Prevention and Control, PAHO/WHO Representation in Panama, Panama; 2006.

79. Mertens DM, McLaughlin JA. Research and evaluation methods in special education. Corwin Press; 2004.

80. World Health Organization. Eliminate Yellow fever Epidemics (EYE): a global strategy, 2017-2026. Wkly Epidemiol Rec [Internet]. 2017 [cited 2018 Mar 26]; 92(16):193-204. Available from: http://apps.who. int/iris/bitstream/handle/10665/ 255040/WER9216.pdf?sequence=1.

\title{
APPENDIX
}

Outcomes measured in the paper Stakeholders involved in the ISC Proponent/Initiator of the ISC

- Academe and Research Institutes

- Civil Society Organization

- Community

- Government agency - Ministry of Health

- Government agency - Other

- Industry

- Multilateral organization

Specified goal/purpose of the ISC

- Primary

Source and type of resources of the ISC

- Secondary

\author{
Source and type of resources of the ISC
}

Strategies or activities implemented by the ISC

Corresponding outputs and outcomes of the strategies implemented by the ISC

- Financial

- Human

- Material

- Policy or Political support

- Advocacy

- Health education

- Health research

- Public health measure

- Resource mobilization

- Service delivery or provision

- Training

Mechanisms for monitoring and evaluation of ISC Gaps encountered by the ISC

- Administrative

- Resource

- Policy

- Research

- Training 